\title{
Effects of rations containing formaldehyde-protected soybean meal on meat production in Kacang goats
}

\author{
Retno Adiwinarti ${ }^{1}$, I. Gede Suparta Budisatria², K. Kustantinah³ ${ }^{3}$ R. Rusman ${ }^{4}$ and Edwin Indarto ${ }^{3}$
}

1. Department of Animal Science, Faculty of Animal and Agricultural Sciences, Diponegoro University, Semarang, Indonesia; 2. Department of Animal Production, Faculty of Animal Science, Gadjah Mada University, Yogyakarta, Indonesia; 3. Department of Animal Nutrition and Feeds Science, Faculty of Animal Science, Gadjah Mada University, Yogyakarta, Indonesia; 4. Department of Animal Product Technology, Faculty of Animal Science, Gadjah Mada University, Yogyakarta, Indonesia.

Corresponding author: Retno Adiwinarti, e-mail: retno_adi@yahoo.co.id Co-authors: IGSB: budisatria@ugm.ac.id, KK: kustantinah@ugm.ac.id, RR: rusman@ugm.ac.id, EI: edwin.indarto@ugm.ac.id

Received: 08-02-2019, Accepted: 07-05-2019, Published online: 25-06-2019

doi: 10.14202/vetworld.2019.890-895 How to cite this article: Adiwinarti R, Budisatria IGS, Kustantinah K, Rusman R, Indarto $E$ (2019) Effects of rations containing formaldehyde-protected soybean meal on meat production in Kacang goats, Veterinary World, 12(6): 890-895.

\begin{abstract}
Aim: This study aimed to investigate effects of rations containing formaldehyde-protected soybean meal on meat production in Kacang goats.

Materials and Methods: Fourteen yearling Kacang bucks, weighing 15.8-19.8 kg, were arranged in a completely randomized design. The treatments included a control (PSBM0): 100\% untreated SBM; PSBM50: 50\% untreated SBM + 50\% formaldehyde-protected SBM; and PSBM100: 100\% formaldehyde-protected SBM.

Results: The goats disliked the protected SBM. Therefore, differences in their intakes were reflected in their average daily gain (ADG). The ADG and slaughtered weight of the control group were the highest, while those of the PSBM100 and PSBM50 groups were similar. The carcass weights and meat production of the control group were higher than those of the PSBM50 group, but the retained protein to the meat conversion ratio of the PSBM50 group was lower than that of the control. The carcass percentages were similar between the treatments.
\end{abstract}

Conclusion: The retained protein to meat conversion ratio of Kacang goats fed with $50 \%$ formaldehyde-protected SBM showed the lowest value, indicating that these rations efficiently produced meat in the carcass.

Keywords: carcass, chevon quality, daily gain, Kacang goat, soybean meal.

\section{Introduction}

Genetic structure and environmental factors both have effects on productivity [1]. Kacang goats are one of the indigenous goat species in Indonesia, raised traditionally in rural areas. The productivity of some Kacang goats is low because the goats are poorly fed and graze on natural grass. The performance of Kacang goats has been improved using soybean meal (SBM) and fish meal in rations [2]. Adiwinarti et al. [2] reported that the dry matter intake of rations containing SBM was higher than those of rations containing fish meal. However, SBM is highly degradable in the rumen [3]. The dry matter digestibility of a rice straw diet supplemented with SBM for goats was 59.5\% [4]. In addition, the degradability of SBM, using an in situ technique, in Cashmere goats after incubation for 12 and $24 \mathrm{~h}$ was approximately 64.75 and $80.57 \%$ of the dry matter, respectively [5].

Copyright: Adiwinarti, et al. Open Access. This article is distributed under the terms of the Creative Commons Attribution 4.0 International License (http://creativecommons.org/licenses/ by/4.0/), which permits unrestricted use, distribution, and reproduction in any medium, provided you give appropriate credit to the original author(s) and the source, provide a link to the Creative Commons license, and indicate if changes were made. The Creative Commons Public Domain Dedication waiver (http:// creativecommons.org/publicdomain/zero/1.0/) applies to the data made available in this article, unless otherwise stated.
Many efforts to protect feed from degradation in the rumen have been attempted [6]. Formaldehyde is a chemical used in animal nutrition, is environmentally safe, [7] and can lower protein degradation in the rumen [8]. Mahima et al. [8] reported that the use of $1.5 \%$ formaldehyde protected mustard oil cake and increased the in vitro digestibility of indigestible protein in wheat straw. Formaldehyde can also decrease the in vitro degradability of SBM in the rumen. Suhartanto et al. [9] reported that the in vitro dry matter degradability of SBM was $89.9 \%$, while that of $0.5 \%$ and $1 \%$ formaldehyde-protected SBM was $52.3 \%$ and $35.3 \%$, respectively. Although formaldehyde-protected SBM has been applied in cattle [10-13] and sheep [14-17], its application in goats is still limited. However, there has been researching on using formaldehyde protection in goats for sesame cake instead of SBM [18].

Beigh et al. [19] studied total mixed rations (TMR) to improve the intake and nutrient utilization of ruminants. The TMR comprised blended concentrate, roughage [19], a protein source, minerals, vitamins to form balance, and economical rations [19-21]. Feed with low palatability can be mixed in TMR to increase the intake [21]. Feed efficiency increased by approximately $4 \%$ when using TMR compared to concentrate and roughage given separately [20]. 
Therefore, this research studied the effects of SBM protected by $1 \%$ formaldehyde in TMR on the growth, carcass production, and chevon quality of Kacang goats. To increase the productivity of goats, the optimum ratio of protected SBM as a function of the physical and chemical properties was explored.

\section{Materials and Methods}

\section{Ethical approval}

The procedures concerning the use of animals in this experiment were approved by the Animal Ethics Committee of the Faculty of Animal and Agricultural Sciences, Diponegoro University, Semarang, Indonesia.

\section{Materials}

Fifteen Kacang bucks, a year of age (indicated by having a total of two permanent incisors), were arranged in a completely randomized design. However, one of the goats in the PSBM100 group died during the research; therefore, only 14 goats were used in this research. Their body weights ranged from 15.8 to $19.8 \mathrm{~kg}$, with an average of $17.6 \pm 1.2 \mathrm{~kg}$. The rations consisted of $30 \%$ Pennisetum purpureum, $30 \%$ Gliricidia leaves, $19.2 \%$ cassava waste products, $13.8 \%$ wheat bran, $7 \% \mathrm{SBM}$, and $1 \%$ mineral mix. In addition, it contained $14-15 \%$ crude protein and $56-60 \%$ total digestible nutrients.

\section{Methods}

A completely randomized design was used in this experiment. The treatments included a control or PSBM0 group: $100 \%$ untreated SBM; PSBM50 group: $50 \%$ untreated SBM $+50 \%$ formaldehyde-protected SBM; and PSBM100 group: 100\% formaldehyde-protected SBM.

The SBM was protected with $1 \%$ formaldehyde. Formalin, containing 37\% formaldehyde diluted 4 times with water, was sprayed on the SBM, and then the treated SBM was fermented overnight. Afterward, the SBM was aerated for 1 day and sun-dried for 2 days. The goats were weighed weekly, over 94 days, and the average daily gain (ADG) was calculated using linear regression [2].

The retained protein was calculated from the protein intake minus the fecal and urinary protein. Between the $8^{\text {th }}$ and $10^{\text {th }}$ weeks of the experiment, daily feces and urine were collected, weighed, and sampled. The procedures used for the fecal and urine sampling were based on those of Darlis et al. [4] and Elamin et al. [22], respectively.

Goats were weighed and slaughtered after a $12 \mathrm{~h}$ fast, with free access to drinking water. The goats were slaughtered, according to Pratiwi et al. [23], but carcasses in this research included the kidney and surrounding fat. Carcasses were weighed and deboned to evaluate the total bone, fat, meat, meat to bone ratio, and retained protein to meat conversion ratio. The retained protein to meat conversion ratio was calculated as the retained protein divided by the meat product.
Biceps femoris muscles were used for the physical and chemical quality assays, which were based on the methods of Mirdhayati et al. [24]. The physical qualities of chevon included the $\mathrm{pH}$, water-holding capacity (WHC), cooking loss, and tenderness obtained from Warner-Bratzler shear force value, which were observed based on the methods of Shirima et al. [25] and Moawad et al. [26]. The chemical qualities of chevon included the water, fat, protein, and collagen content, which were determined using near-infrared spectroscopy [27]. Data were analyzed as a completely randomized design using one-way ANOVA [28].

\section{Results}

\section{The ADG, carcass, and meat production}

The dry matter intake (DMI) of the PSBM50 group was lower $(p<0.01)$ than that of the control (PSBM0) group, however, the DMI of the PSBM50 and PSBM0 groups was not significantly different ( $>0.05)$ from that of the PSBM100 group (Table-1). Differences in their intakes were reflected in their live weight (Figure-1), ADG, slaughter weight, carcass weight, and meat weight (Tables-1 and 2). The live weight, ADG, slaughtered weight, carcass weight, and meat weight of the PSBM0 group were higher than those of the PSM50 and PSM100 groups (Figure-1), while those of the PSBM50 and PSBM100 groups were about same (Tables-1 and 2).

The carcass and meat weight of the PSBM50 group were lower than those of the PSBM0 group. Surprisingly, although the meat weight of the PSBM50 group was lower than that of the PSBM0 group, the retained protein to the meat conversion ratio of the PSBM50 group was the lowest (Table-3). The lower the value of the retained protein to meat conversion ratio, the better the ration, because this indicates that the amount of retained protein required to convert a gram of meat was lower.

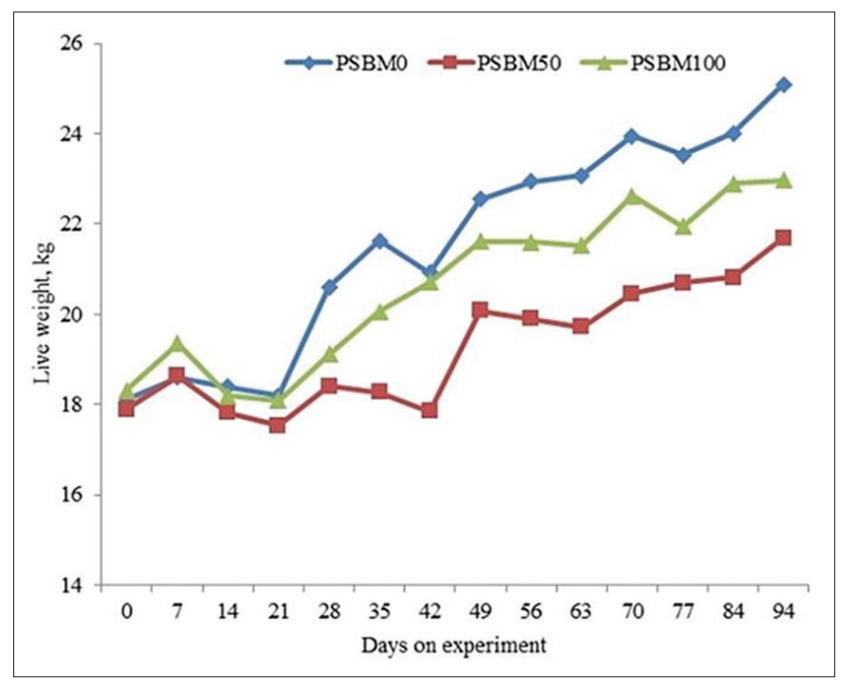

Figure-1: Body weight of Kacang goats receiving formaldehyde-protected soybean meal 0\% (PSBM0), 50\% (PSBM50), and 100\% (PSBM100). 
Table-1: The DMI, ADG, slaughter weight, carcass weight, and carcass percentage.

\begin{tabular}{lcccc}
\hline Parameters & PSBMO $^{\text {(control) }} \mathbf{1}^{\mathbf{1}}$ & PSBM50 $^{\mathbf{2}}$ & PSBM100 $^{\mathbf{3}}$ & p-value $^{-}$ \\
\hline DMI, g & $701.3 \pm 81.6^{\mathrm{A}}$ & $541.1 \pm 41.6^{\mathrm{B}}$ & $606.9 \pm 65.9^{\mathrm{AB}}$ & 0.008 \\
ADG, g & $78.9 \pm 10.3^{\mathrm{A}}$ & $41.5 \pm 15.2^{\mathrm{B}}$ & $56.5 \pm 5.0^{\mathrm{B}}$ & 0.001 \\
Slaughter weight, kg & $25.1 \pm 1.3^{\mathrm{A}}$ & $21.7 \pm 1.1^{\mathrm{B}}$ & $23.0 \pm 0.6^{\mathrm{B}}$ & 0.001 \\
Carcass weight, kg & $11.6 \pm 1.0^{\mathrm{A}}$ & $9.5 \pm 0.8^{\mathrm{B}}$ & $10.1 \pm 0.4^{\mathrm{AB}}$ & 0.006 \\
Carcass percent, \% & $46.2 \pm 3.6$ & $43.8 \pm 2.1$ & $43.8 \pm 2.1$ & 0.337 \\
\hline
\end{tabular}

DMI=Dry matter intake; $A D G=$ Average daily gain. $A, B$ within a row, means without a common uppercase superscript differ $\left(p<0.01\right.$ ). ${ }^{1}$ PSBMO (control) means 100\% untreated SBM. ${ }^{2}$ PSBM50 means $50 \%$ untreated SBM $+50 \%$ formaldehyde-protected SBM. ${ }^{3}$ PSBM100 means 100\% formaldehyde-protected SBM. SBM=Soybean meal

Table-2: Carcass components and meat to bone ratio.

\begin{tabular}{lcccc}
\hline Parameters & PSBMO (control) $^{\mathbf{1}}$ & PSBM50 $^{\mathbf{2}}$ & PSBM100 $^{\mathbf{3}}$ & p-value $^{-}$ \\
\hline Meat, kg & $8.1 \pm 0.9^{\mathrm{a}}$ & $6.5 \pm 0.6^{\mathrm{b}}$ & $7.2 \pm 0.1^{\mathrm{a}, \mathrm{b}}$ & 0.013 \\
Meat, \% & $71.1 \pm 3.1$ & $69.6 \pm 1.3$ & $73.1 \pm 1.4$ & 0.086 \\
Fat, kg & $1.1 \pm 0.2$ & $0.9 \pm 0.1$ & $0.7 \pm 0.3$ & 0.099 \\
Fat, \% & $9.5 \pm 2.5$ & $9.2 \pm 0.7$ & $7.4 \pm 2.6$ & 0.320 \\
Bone, kg & $2.2 \pm 0.2$ & $2.0 \pm 0.1$ & $1.9 \pm 0.2$ & 0.112 \\
Bone,\% & $19.4 \pm 1.6$ & $21.2 \pm 1.5$ & $19.5 \pm 1.7$ & 0.182 \\
Meat+fat to bone ratio & $4.2 \pm 0.4$ & $3.7 \pm 0.3$ & $4.2 \pm 0.4$ & 0.187 \\
Meat to bone ratio & $3.7 \pm 0.4$ & $3.3 \pm 0.3$ & $3.8 \pm 0.3$ & 0.124 \\
\hline
\end{tabular}

a,bWithin a row, means without a common uppercase superscript differ $(\mathrm{p}<0.05)$. ${ }^{1}$ PSBM0 (control) means $100 \%$ untreated SBM. ${ }^{2}$ PSBM50 means 50\% untreated SBM+50\% formaldehyde-protected SBM. ${ }^{3}$ PSBM 100 means $100 \%$ formaldehyde-protected SBM. SBM=Soybean meal

Table-3: Retained protein to meat conversion ratio.

\begin{tabular}{|c|c|c|c|c|}
\hline Parameters & PSBMO (control) ${ }^{1}$ & PSBM50 $^{2}$ & PSBM100 3 & p-value \\
\hline Retained protein, $\mathrm{g}$ & $59.5 \pm 19.3^{A}$ & $24.1 \pm 2.8^{B}$ & $42.4 \pm 2.4^{\mathrm{AB}}$ & 0.002 \\
\hline Meat, $g$ & $8078.6 \pm 978.9^{a}$ & $6472.5 \pm 615.7^{b}$ & $7226.7 \pm 141.0^{\mathrm{ab}}$ & 0.013 \\
\hline Retained protein to meat conversion ratio & $0.007 \pm 0.002^{\mathrm{A}}$ & $0.004 \pm 0.001^{\mathrm{Bb}}$ & $0.006 \pm 0.000^{\mathrm{Aa}}$ & 0.002 \\
\hline
\end{tabular}

$A, B$ Within a row, means without a common uppercase superscript differ $(p<0.01)$. a,b Within a row, means without a common uppercase superscript differ $(p<0.05)$. ${ }^{1}$ PSBM0 (control) means $100 \%$ untreated SBM. ${ }^{2}$ PSBM50 means $50 \%$ untreated SBM+50\% formaldehyde-protected SBM. ${ }^{3}$ PSBM 100 means $100 \%$ formaldehyde-protected SBM. SBM=Soybean meal

The carcass and meat weight of the PSBM50 and PSBM0 groups were not significantly different $(\mathrm{p}>0.05)$ from the PSBM100 group (Tables-1 and 2). In fact, the carcass and meat percentage were similar between the treatments (Tables-1 and 2). The averages of the carcass and meat percentages were 44.6 and $71.2 \%$, respectively. The fat, bone, meat + fat to bone ratio, and meat to bone ratio were also similar between the treatments (Table-2), with average values of $0.9 \mathrm{~kg}(8.7 \%), 2.0 \mathrm{~kg}(20.0 \%), 4.0$, and 3.6, respectively.

\section{The chevon quality}

The physical qualities of the chevon were almost the same between the treatments, with average values of $\mathrm{pH} 6.0$, WHC $39.8 \%$, cooking loss $37.2 \%$, and tenderness $6.8 \mathrm{~kg} / \mathrm{cm}^{2}$ (Table-4). The chemical qualities of the chevon were also the same between the treatments, with average values of moisture $72.8 \%$, protein $21.6 \%$, fat $2.6 \%$, and collagen content $1.9 \%$ (Table- 4 ).

\section{Discussion}

\section{The ADG, carcass, and meat production}

The ADG of the goats was influenced by the feed intake. Goats that consumed more feed showed a higher body weight gain. The lower intake of goats fed with rations containing formaldehyde-protected SBM (PSBM50 and PSBM100) indicates that Kacang goats did not like the palatability of the rations because goats are selective feeders, as stated by Rahman et al. [29]. Although the DMI of the goats fed formaldehyde-protected SBM (541.1 and $606.9 \mathrm{~g}$ for PSBM50 and PSBM100, respectively) in this research were lower than those of the goats in Rahman et al. [29], their ADG was higher (41.5 and $56.5 \mathrm{~g}$ for PSBM50 and PSBM100, respectively, vs. 30.8-43.5 g for Rahman et al. research). The ADG of the goats fed PSBM0 (78.9 g) was higher than that of the Kacang goats reported by Restitrisnani et al. [30] (23.5-69.4 g). However, Rahman et al. [31] reported that crossbred Boer goats fed with soy waste products and P. purpureum had a weight gain of $80.2 \mathrm{~g} / \mathrm{d}$.

The range of carcass weights of Kacang goats in this research $(9.5-11.6 \mathrm{~kg})$ was relatively similar to that of Kacang goats in Gafar et al. [32] (10.7-12.2 kg). However, Kacang goat carcasses were heavier than Indian local goat carcasses, as Solanki et al. [33] reported that Indian local goats had carcass weights of $6.1-7.2 \mathrm{~kg}$ at $6-7$ months and slaughter weights of 13.2-15.0 kg. In contrast, Hwangbo et al. [34] reported that Korean Black goats had carcass weights 
Table-4: Physical and chemical quality of the chevon.

\begin{tabular}{|c|c|c|c|c|}
\hline Parameters & PSBMO (control) ${ }^{1}$ & PSBM50² $^{2}$ & PSBM100 3 & p-value \\
\hline \multicolumn{5}{|l|}{ Physical quality } \\
\hline $\mathrm{pH}$ & $6.0 \pm 0.1$ & $6.0 \pm 0.1$ & $6.0 \pm 0.1$ & 0.890 \\
\hline WHC, \% & $39.1 \pm 1.9$ & $40.2 \pm 2.0$ & $40.4 \pm 3.9$ & 0.740 \\
\hline Cooking loss, \% & $37.1 \pm 2.5$ & $38.0 \pm 2.3$ & $36.3 \pm 3.1$ & 0.620 \\
\hline Tenderness, kg/ $\mathrm{cm}^{2}$ & $6.9 \pm 0.1$ & $6.8 \pm 0.3$ & $6.8 \pm 0.3$ & 0.820 \\
\hline \multicolumn{5}{|l|}{ Chemical quality } \\
\hline Moisture, \% & $72.3 \pm 0.8$ & $72.9 \pm 1.1$ & $73.2 \pm 0.9$ & 0.383 \\
\hline Protein, \% & $22.2 \pm 0.9$ & $21.5 \pm 0.7$ & $21.0 \pm 0.8$ & 0.150 \\
\hline Fat, \% & $2.8 \pm 0.4$ & $2.5 \pm 0.6$ & $2.3 \pm 0.5$ & 0.420 \\
\hline Collagen, \% & $1.9 \pm 0.2$ & $2.0 \pm 0.2$ & $2.0 \pm 0.1$ & 0.653 \\
\hline
\end{tabular}

WHC $=$ Water-holding capacity. ${ }^{1}$ PSBM0 (control) means 100\% untreated SBM. ${ }^{2}$ PSBM50 means 50\% untreated SBM+50\% formaldehyde-protected SBM. ${ }^{3}$ PSBM100 means 100\% formaldehyde-protected SBM. SBM=Soybean meal

of $16.3-17.0 \mathrm{~kg}$ at 6 months and slaughter weights of $31.0-31.7 \mathrm{~kg}$. Based on these studies, it can be concluded that carcass weights are influenced by the slaughter weight, age at slaughter, and breed. In addition, Yusuf et al. [35] reported that a heavier carcass was due to higher feed intake and better weight gain. Kacang goats are a local Indonesian goat that has a small body size (Kacang means that the goat is as small as a peanut); therefore, the carcass weight is also low. However, because they are prolific and adaptable to poor feeding management, Kacang goats are widely reared by farmers in villages.

The carcass percentages were similar between the treatments. This indicates that the carcass percentage was influenced by the carcass and slaughter weights. The carcass percentages of Kacang goats in this study (43.8-46.2\%) were lower than those of Kacang goats reported by Gafar et al. [32] (53.3-56.8\%), or other breeds reported by Johnson et al. [36] (49.4-49.9\%) and Hwangbo et al. [34] (51.6-54.4\%). However, they were relatively similar to those reported by Hutama [37] (46.7\%), Solanki et al. [33] (46.0-48.2\%), Singh et al. [38] (44.747.6\%), Yusuf et al. [35] (40.3-48.1\%), and Akbaş and Saatci [39] (43.9-46.1\%), while they were higher than those reported by Sumardianto et al. [40] (40.9\%) and Adiwinarti et al. [41] (38.8\%). The differences between the carcass percentages, which varied between $35 \%$ and $53 \%$, were caused by the different feeds, feeding management systems, genotype, sex, and age [39]. However, Das and Rajkumar [42] reported that the dressing percentage was less influenced by the breed. In fact, the dressing percentage was mostly influenced by the slaughter weight $[34,39]$.

Meat produced from the PSBM0 (control) group was more than that of the PSBM50 group (Table-2) due to the higher DMI, protein intake, and retained protein. However, the retained protein to the meat conversion ratio of the PSBM50 group was significantly lower $(\mathrm{p}<0.01)$ than that of the PSBM0 (control) group (Table-3). This indicated that the PSBM50 ration has the potential to increase meat production, but further research is needed to increase the DMI of the PSBM50 ration.
The meat percentages in this study (69.6-73.1\%) were similar to those of the control goats in Yusuf et al. [35] (69.3\%). However, they were lower than those of the goats fed Andrographis paniculata (83.1$84.1 \%$ ) [35], and higher than those in the studies of Hwangbo et al. [34] (58.1-59.6\%), Aktaş et al. [43] (53.7-57.9\%), and Ayeb et al. [44] (54.7-61.7\%). Ayeb et al. [44] stated that the diet did not directly influence the meat percentages, as the goats had similar slaughter weights.

In this study, the fat percentage (7.4-9.5\%) was lower than that reported by Aktaş et al. [43] (8.8-12.4\%) and Yusuf et al. [35] (9.5-21.8\%). The fat percentage was influenced by the slaughter weight. Never [45] reported that heavier animals produce a higher proportion of fat and lower proportion of muscle and bone. In this study, the slaughter weight $(21.7-25.1 \mathrm{~kg})$ was lower than that reported by Aktaş et al. [43] $(25.0-38.8 \mathrm{~kg})$ and Yusuf et al. [35] (25.7-31.8 kg).

In this study, the bone percentage (1.9-2.2\%) was higher than that in Hwangbo et al. [34] (18.1-18.9\%) and Yusuf et al. [35] (8.4-12.0\%). This difference is due to the different slaughter weights. Ayeb et al. [44] reported that the bone percentage was similar between the diet treatments as the goats have the same slaughter weight.

In this study, the meat to bone ratio of Kacang goats (3.3-3.8) was higher than that reported by Sumardianto et al. [40] (2.6) or Adiwinarti et al. [41] (2.2), but lower than that reported by Yusuf et al. [35] (6.2-9.9). Never [45] stated that the carcass composition was affected by the nutrient intake, feed composition, and nutrient requirements of the animal.

\section{The chevon quality}

The physical quality of the carcass was not influenced by the diet [46]. The $\mathrm{pH}$ of chevon in this study was lower than that reported by Adiwinarti et al. [41] in traditionally managed Kacang goats $(\mathrm{pH}: 6.3)$. The high $\mathrm{pH}$ caused the high WHC, as Judge et al. [47] stated that the higher the $\mathrm{pH}(5.2-6.8)$, the more protein-bound water is present and the higher the WHC. The tenderness was similar between the treatments because the collagen contents were the same. 
Hwangbo et al. [34] reported that the chemical compositions of chevon in Korean black goats were not different between the treatments (the level of protein content started from $14 \%$ to $20 \%$ ). The water content was influenced by the fat content. The high water content in this study might be caused by the low-fat content of the chevon [24,34]. Mirdhayati et al. [24] reported that the water content of Kacang goats was $73.8-74.5 \%$ and the fat content was $0.4-0.5 \%$, while Hwangbo et al. [34] reported that the moisture content of the Korean Black goat, fed TMR, was 74.3$74.8 \%$ and the fat content was $1.4-1.7 \%$. The protein content $(21.0-22.2 \%)$ was lower than that reported by Mirdhayati et al. [24] (23.2-23.5\%), but relatively similar to that reported by Hwangbo et al. [34] (21.7$22.5 \%$ ), and higher than that reported by Adiwinarti et al. [41] (19.6-19.7\%).

\section{Conclusion}

Goats fed PSBM0 had the best ADG, slaughter weight, carcass weight, and meat products due to the higher DMI. However, goats fed PSBM50 rations were the most efficient meat producers, which was indicated by the lowest retained protein to meat conversion ratio.

\section{Authors' Contributions}

RA conducted the experiment, acquisition of data, and drafting of the manuscript. IGSB advised in the design of the experiment, data analysis, and interpretation. KK developed the feeding concepts and supervised the experiment. RR advised on the analysis and interpretation of the post-mortem data. EI supervised nutrition analyses. All the authors accepted the final manuscript.

\section{Acknowledgments}

The authors are very grateful for the financial support of the Directorate Research and Community Service, Directorate General of Higher Education, the Ministry of Research, Technology, and Higher Education, Republic of Indonesia (Research Grant "Penelitian Unggulan Perguruan Tinggi" Universitas Gadjah Mada, No. 001/SP2H/LT/DRPM/IV/2017). The authors are also grateful for the assistance with collecting data of the "Kacang goat" team and Diponegoro University, Meat Science Laboratory assistants. Finally, we would like to thank Prof. Shigeru Hayakawa (Kagawa University, Japan) for proofreading the manuscript.

\section{Competing Interests}

The authors declare that they have no competing interests.

\section{Publisher's Note}

Veterinary World remains neutral with regard to jurisdictional claims in published institutional affiliation.

\section{References}

1. Çilek, S. and Tekin, M.E. (2005) Environmental factors affecting milk yield and fertility traits of Simmental cows raised at the Kazova state farm and phenotypic correlations between these traits. Turk. J. Vet. Anim. Sci., 29(4): 987-993.

2. Adiwinarti, R., Kustantinah, Budisatria, I.G.S., Rusman, and Indarto, E. (2016) Improving the performance of local Kacang goats using rumen undegradable protein feeds. Asian J. Anim. Sci., 10(4): 262-267.

3. Falahatizow, J., Mesgaran, M.D., Vakili, A.R., Tahmasbi, A.M. and Nazari, M.R. (2015) The estimation of ruminal protein degradation parameters of various feeds using in vitro modified gas production technique. Iran. $J$. Vet. Res., 16(1): 47-52.

4. Darlis, Abdullah, N., Halim, R.A., Jalaludin, S. and Ho, Y.W. (2000) Effects of protein and carbohydrate supplements on feed digestion in indigenous Malaysian goats and sheep. Asian Australas. J. Anim. Sci., 13(4): 464-469.

5. Lei, Y.G., Li, X.Y., Wang, Y.Y., Li, Z.Z., Chen, Y.L. and Yang, Y.X. (2018) Determination of ruminal dry matter and crude protein degradability and degradation kinetics of several concentrate feed ingredients in cashmere goat. J. Appl. Anim. Res., 46(1): 134-140.

6. Haryanto, B. (2014) Manipulating protein degradability in the rumen to support higher ruminant production. Wartazoa, 24(3): 131-138.

7. European Food Safety Authority (EFSA) FEEDAP Panel (EFSA Panel on Additives and Products or Substances used in Animal Feed). (2014) Scientific Opinion on the safety and efficacy of formaldehyde for all animal species based on a dossier submitted by Regal BV. EFSA J., 12(2): 3561.

8. Mahima, Kumar, V., Tomar, S.K., Roy, D. and Kumar, M. (2015) Effect of varying levels of formaldehyde treatment of mustard oil cake on rumen fermentation, digestibility in wheat straw based total mixed diets in vitro. Vet. World, 8(4): 551-555.

9. Suhartanto, B., Utomo, R., Kustantinah, Budisatria, I.G.S., Yusiati, L.M. and Widyobroto, B.P. (2014) The effect of formaldehyde inclusion on undegraded protein processing and its supplementation level on complete feed pellet on in vitro rumen microbial activities. Bul. Peternakan, 38(3): 141-149.

10. Mahadevan, S., Teather, R.M., Erfle, J.D. and Sauer, F.D. (1983) Effect of formaldehyde treatment of soybean meal on rates of protein degradation and microbial protein concentration in the bovine rumen. Can. J. Anim. Sci., 63(1): 181-190.

11. Crooker, B.A., Clark, J.H. and Shanks, R.D. (1983) Effects of formaldehyde-treated soybean meal on milk yield, milk composition, and nutrient digestibility in the dairy cow. $J$. Dairy Sci., 66(3): 492-504.

12. Perdhana, P.W., Riyanto, J., Ratriyanto, A., Widyawati, S.D. and Suprayogi, W.P.S. (2013) Pengaruh penggunaan tepung ikan dan menir kedelai terproteksi dalam ransum terhadap kecernaan nutrien pada sapi persilangan simmental peranakan ongole jantan. Trop. Anim. Husbandry, 2(1): 1-7.

13. Rochijan, Widyobroto, B.P. and Ismaya (2016) Effect of high rumen undegraded protein (HRUP) supplementation on estrous response and progesterone hormone profile in dairy cows raised under Indonesia tropical environmental conditions. Asian J. Anim. Sci., 10(3): 175-181.

14. Fiems, L.O., Cottyn, B.G., Boucqué, C.V. and Buysse, F.X. (1987) Effect of formaldehyde-treated soya bean meal and urea in starters on nitrogen quality, degradability in sacco, sheep digestibility and calf performance. Anim. Feed Sci. Technol., 16(4): 287-295.

15. Yörük, M.A., Aksu, T., Gul, M. and Bolat, D. (2006) The effect of soybean meal treated with formaldehyde on amount of protected protein in the rumen and absorption of amino acid from small intestines. Turk. J. Vet. Anim. Sci., 30(5): 457-463. 
16. Abdel-Ghani, A.A., Solouma, G.M.A., Abd Elmoty, A.K.I., Kassab, A.Y. and Soliman, E.B. (2011) Productive performance and blood metabolites as affected by protected protein in sheep. Open J. Anim. Sci., 1(2): 24-32.

17. Riyanto, J. and Sudibya (2018) Evaluation of feed for thintailed sheep fattening with supplemented protected and unprotected aldehyde. IOP Conf. Ser. Earth Environ. Sci., 119(1): 012020.

18. Tiwari, M.R., Ghimire, R.P., Adhikari, D., Adhikari, D.P. and Ghimire, S.H. (2015) Effect of formaldehyde-treated sesame cake feeding on growth performance of growing female goats in fodder based basal diet effect of formaldehyde-treated sesame cake feeding on growth performance of growing female goats in fodder based basal diet. Nepal. J. Agric. Sci., 13(1 Sept. 2015): 14-20.

19. Beigh, Y.A., Ganai, A.M. and Ahmad, H.A. (2017) Prospects of complete feed system in ruminant feeding: A review. Vet. World, 10(4): 424-437.

20. Kmicikewycz, A. and Heinrichs J. (2016) Total Mixed Rations for Dairy Cows: Advantages, Disadvantages, and Feeding Management. The Pennsylvania State University. Available from: http://www.extension.psu.edu. Last accessed on 7-10-2018.

21. Linn, J. (2016) Feeding Total Mixed Rations. The University of Minnesota Extension. Available from: http://www.extension.umn.edu/agriculture/dairy/feed-and-nutrition/feeding-total-mixed-rations. Last accessed on 13-10-2016.

22. Elamin, K.M., Eldar, A.A.T., Amin, A.E., Abdalla, F.S. and Hassan, H.E. (2012) Digestibility and nitrogen balance of Sudan goat ecotypes fed different energy/protein levels. Asian J. Anim. Sci., 6(5): 230-239.

23. Pratiwi, N.M.W., Murray, P.J. and Taylor, D.G. (2007) Feral goats in Australia: A study on the quality and nutritive value of their meat. Meat Sci., 75(2007): 168-177.

24. Mirdhayati, I., Hermanianto, J., Wijaya, C.H. and Sajuthi, D. (2014) Carcass profile and chemical characteristic of male Kacang goat (Capra aegragus hircus). Indones. J. Anim. Vet. Sci., 19(1): 26-34.

25. Shirima, E.J.M., Mtenga, L.A., Kimambo, A.E., Laswai, G.H., Mgheni, D.M., Mushi, D.E., Shija, D.S., Safari, J.G. and Hozza, W.A. (2013) Effects of days in feedlot on physic-chemical properties and meat tenderness from Tanzanian long fat-tailed sheep. J. Anim. Prod. Adv., 3(2): 40-48.

26. Moawad, R.K., Mohamed, G.F., Ashour, M.M.S. and El-Hamzy, E.M.A. (2013) Chemical composition, quality characteristics and nutritive value of goat kids' meat from Egyptian Baladi breed. J. Appl. Sci. Res., 9(8): 5048-5059.

27. Prevolnik, M., Candek-Potokar, M. and Skorjanc, D. (2004) Ability of NIR spectroscopy to predict meat chemical composition and quality-a review. Czech J. Anim. Sci., 49(11): 500-510.

28. Steel, R.G.D. and Torrie, J.H. (1980) Principles and Procedures of Statistics. $2^{\text {nd }}$ ed. McGraw-Hill, Inc., New York

29. Rahman, M.M., Abdullah, R.B., Khadijah, W.E.W., Nakagawa, T. and Akashi, R. (2015) Feed intake and growth performance of goats fed with Napier grass and oil palm frond supplemented with soya waste. J. Appl. Anim. Res., 43(3): 256-260.

30. Restitrisnani, V., Purnomoadi, A. and Rianto, E. (2013) The production and body composition of Kacang goat fed different quality of diets. J. Indones. Trop. Anim. Agric., 38(3): 163-170.

31. Rahman, M.M., Nakagawa, T., Abdullah, R.B., Embong, W.K.W. and Akashi, R. (2014) Feed intake and growth performance of goats supplemented with soy waste. Pesq. Agropec. Bras., 49(7): 554-558.

32. Gafar, A.A., Alimon, A.R., Sazili, A.Q., Man, Y.C. and Abubakr, A.R. (2013) Effect of varying levels of palm oil decanter cake on feed intake, growth performance and carcass characteristics of Kacang goats. IOSR J. Agric. Vet. Sci., 3(4): 24-29.

33. Solanki, C.P.S., Nanavati, S., Nayak, N.K. and Bhadoria, H.B.S. (2009) Carcass traits of local goats under different managemental systems. Indian J. Anim. Sci., 79(12): 1277-1279.

34. Hwangbo, S., Choi, S.H., Kim, S.W., Son, D.S. and Park, H.S. (2009) Effects of crude protein levels in total mixed rations on growth performance and meat quality in growing Korean black goats. Asian Australas. J. Anim. Sci., 22(8): 1133-1139.

35. Yusuf, A.L., Goh, Y.M., Samsudin, A.A., Alimon, A.R. and Sazili, A.Q. (2014) Growth performance, carcass characteristics and meat yield of Boer goats fed diets containing leaves or whole parts of Andrographis paniculata. Asian Australas. J. Anim. Sci., 27(4): 503-510.

36. Johnson, C.R., Doyle, S.P. and Long, R.S. (2010) Effect of feeding system on meat goat growth performance and carcass traits. Sheep Goat Res. J., 25(2010): 78-82.

37. Hutama, Y.G. (2014) The Percentage of Carcass and Non-carcass Component of Male Kacang Goats Fed with Different Levels of Protein and Energy. [Bachelor Thesis]. Diponegoro University; 2014. Available from: http://www. eprints.undip.ac.id/42789. Last accessed on 23-9-2014.

38. Singh, M.K., Dutta, T.K., Sharma, R.B., Das, A.K. and Singh, N.P. (2010) Evaluation of growth, feed conservation efficiency and carcass traits of Jamunapari goats under intensive feeding system. Indian J. Anim. Sci., 80(4): 382-384.

39. Akbaş, A.A. and Saatci, M. (2016) Growth, slaughter, and carcass characteristics of honamli, hair, and honamli x hair (F1) male goat kids bred under extensive conditions. Turk. J. Vet. Anim. Sci., 40(4): 459-467.

40. Sumardianto, T.A.P., Purbowati, E. and Masykuri (2013) Carcass characteristic of male Kacang, Ettawa crossbred, and Kejobong goat at one year old. Anim. Agric. J., 2(1): 175-182.

41. Adiwinarti, R., Budisatria, I.G.S., Kustantinah and Rusman (2015) Carcass Production and Chevon Quality of Kacang Buck Reared Traditionally in Grobogan, Central Java, Indonesia. In: Proceedings the $6^{\text {th }}$ International Seminar on Tropical Animal Production (ISTAP) Integrated Approach in Developing Sustainable Tropical Animal Production. Yogyakarta, Indonesia, October 20-2, 2015. Faculty of Animal Science, Universitas Gadjah Mada Yogyakarta, Indonesia. p694-698.

42. Das, A.K. and Rajkumar, V. (2010) Comparative study on carcass characteristics and meat quality of three Indian goat breeds. Indian J. Anim. Sci., 80(10): 1014-1018.

43. Aktaș, A.H., Gok, B., Ates, S., Tekin, M.E., Halici, I., Bas, H., Erduran, H. and Kassam, S. (2015) Fattening performance and carcass characteristics of Turkish indigenous hair and Honamli goat male kids. Turk. J. Vet. Anim. Sci., 39(6): 643-653.

44. Ayeb, N., Ghrab, A., Barmat, A. and Khorchani, T. (2016) Chemical and tissue composition of meat from carcass cuts of local goats affected by different feeding in Tunisian arid lands. Turk. J. Vet. Anim. Sci., 40(2016): 95-101.

45. Never, A. (2015) Some major factors affecting carcass composition in goats. Sci. J. Anim. Sci., 4(7): 81-88.

46. Sebsibe, A., Casey, N.H., Van Niekerk, W.A., Tegegne, A. and Coertze, R.J. (2007) Growth performance and carcass characteristics of three Ethiopian goat breeds fed grainless diets varying in concentrate to roughage ratios. S. Afr. J. Anim. Sci., 37(4): 221-232.

47. Judge, M.D., Aberle, E.D., Forrest, J.C., Hedrick, H.B. and Merkel, R.A. (1989) Principles of Meat Science. $2^{\text {nd }}$ ed. Kendall/Hunt Publishing Company, Dubuque. 